\title{
The New Spectacle: How effective is mobile Augmented Reality as tool for the manifestation of dissent?
}

\author{
Liam Noah Jefferies \\ Leeds Art University \\ Blenheim Walk, Leeds, UK \\ liam.jefferies@leeds-art.ac.uk
}

\section{THE NEW SPECTACLE}

Hordes of Networked AR Creatives deploy Viral Virtual Media to overlay, then overwhelm closed Social Systems lodged in Physical Hierarchies (Manifest.AR 2011).

The above quote taken from the Manifest.AR's (2011) collective manifesto demonstrates the power its founders attributed to augmented reality technology (AR); in particular, its ability to disrupt closed physical hierarchies through a form of technologically induced 'détournement'. Détournement is a stratagem devised, or at least, coined, by Debord (1967) as a method to resist and undermine the pervading spectacle of capitalist society "by challenging the meaning of something taken for granted".

The ability to intercede within closed systems is growing in importance as a reaction to the privatisation of public spaces and the creation of 'quasi-public' or privatised alternatives that has been well documented in both the academic and popular press. Whilst some seek to offer a positive spin on this (Devereux 2017), the pervading tone of this literature indicates that: "the urban spaces that are produced are spaces of order and control, of aesthetic homogeneity and uniformity" (Tran 2015) and beyond "this actively restraining and excluding those deemed not to belong" (Graham 2001, p365).

A reduction in public spaces and the freedom of actions permitted in them, is something that many see as problematic, with several international sites, cited as instrumental in achieving lasting change. Most notable Tehran, Tahrir, Wall Street, Puerta Del Sol, Gezi Park \& Euromaidan, reinforcing the view that open "Public spaces are absolutely essential to the functioning of democratic politics." (Mitchell, 1995).
The focus here will be on a proclaimed ability of Augmented reality intervention to intercede, enabling through creative and technological means, the disruption of the top down control over experience and narrative available in our cities.

An example of this is the Artvertiser (2008) project (theartvertiser.com), which provides an open source tool to subvert advertising billboards, digitally overwriting corporation's adverts with the work of artists. Using image recognition to automatically replace all the iterations of the realworld advert with non-commercialised artistic content and enabling ad busting on a grand scale. Julian Oliver, the projects founder makes the claim that "we are intentionally violated by billboards everyday of our lives... a new kind of dictatorship that one can't escape" (vimeo.com 12/09/17) and whilst Oliver makes no reference to Debord the parallels are plain to see. With the control over the spaces we inhabit, and our lived experience within them firmly in the hands of the corporate and political elite the Artvertiser is offered as a means of resistance.

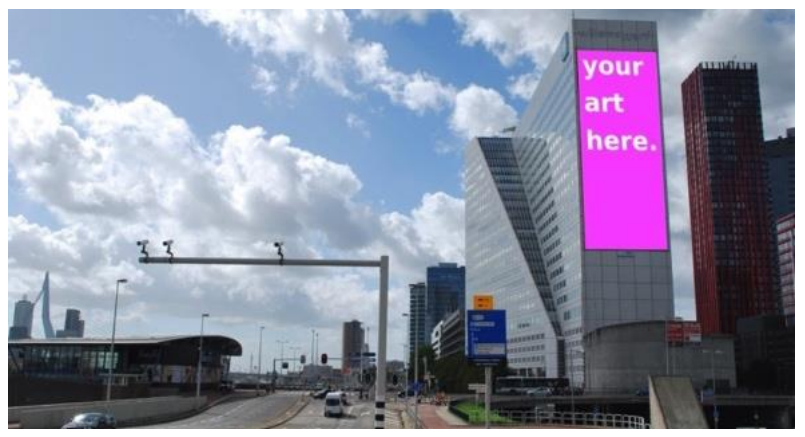

Figure 1: The Artvertiser, Julian Oliver, 2009.

Another example of AR rendered Détournement is Les Liens invisibles artwork, Monument to an invisible pink unicorn. (www.lesliensinvisibles.org 
2011). Where a pink unicorn is placed, using GPS and the Layar app, within St Peter's Square in Rome and is only visible through a connected device, a process that renders it both pink and invisible depending on the viewer's perspective.

The reason this artwork has been cited as an example of Détournement stems from the conflicting and subversive contexts of symbolism and space. With the Invisible Pink Unicorn being recognised as a satirical motif that parodies religion and organised theology, situated within the closed and heavily controlled, quasi-public religious space within the Vatican City. Claiming to alter and subvert the dominant spatial narratives and offer meaning that opposes the spectacle through processes outside closed systems.

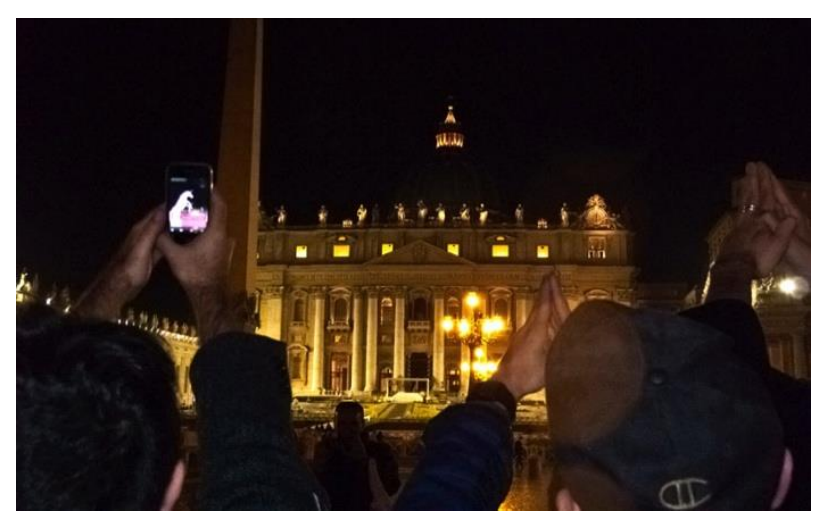

Figure 1: Monument to the invisible pink Unicorn, Les Liens Invisible, St Peter's Square 2011.

Activists have begun working with AR to see its potential as a tool for social change [seeking to] explore what makes AR unique as medium and which of its qualities can be best utilized to further activist causes (Shwarek 2014, p.32).

In the decade since the Artvertiser was conceived and the seven years since Manifest.AR wrote their manifesto, many similar and perhaps even more radical artwork have been created using AR. Such as The4Gentlemans Tiananmen Squared (2012), which recreates the goddess of Democracy, statue on the site of the original protest, or Mark Skwarek's "erase the separation barrier" 2011 that digitally erases the wall that segregates the Palestine's and Israeli's in Gaza. The 2014 book Augmented Reality Art edited and with contributions from Skwarek, expounds AR's ability to challenge dominant spatial narratives. This is supported by thoughtful contributions from many artist/activists engaging in this medium, all of whom seem to dismiss the shortcomings of this medium to effect real world change.

What is perhaps most striking is the lack of traction this medium has gained within this field; If it were such an effective tool to challenge the spectacle of society then would its usage not have spread and its impact been felt? An email exchange with Sander Veenhof, a founding member of manifest.ar offers some indication:

AR brings a lot of freedom into the reality around us. But in the end, some new kind of filtering will need to be implemented (Veenhof 2014).

"Filtering" in this context refers to the means, by which participants access the augmented content; which in the case of mobile devices is currently only achieved though the installation of an application. This process is a significant barrier to mass and widespread engagement with AR content in the way envisioned by Schwarek and others. Primarily due to the disparate ecosystem of applications that have emerged.

AR does appear to offer an opportunity to make powerful and subversive interventions and site them in spaces, which are impactful and potentially antagonistic to the powers that control them. Something that is much needed as our ability to make physical protest is becoming further curtailed. There is a level of separation and of distance, provided by the liminality of $A R$, which can circumvent normal controls.

But it is this very liminality, which is so central to its ability to challenge real-world spatial narratives that is the very thing that prevents it from doing so. Under these conditions, in a space, which is heavily controlled, what scope is there to promote the potential experience to a mass audience? What power does an intervention have to alter perspectives, if nobody knows it is there?

\section{REFERENCES}

Debord, G. (1967) The Society of Spectacle. Rebel Press, London. New edition: 1992.

Devereux, M. and Littlefield, D. (2017) A literature review on the privatisation of public space. Project Report, Report UWE. http://eprints.uwe.ac.uk (retrieved 30 March 2018).

Graham, S. (2001) The spectre of the splintering metropolis. Cities, 18(6):365-368.

Manifest.AR (2011) The AR Art Manifesto. https://armanifesto.wordpress.com (retrieved 12 January 2018).

Mitchell D., (1995) The End of Public Space? People's Park, Definitions of the Public, and Democracy. Annals of the Association of American Geographers, 85(1):115.

Shwarek, M. (2014) Augmented Reality Activism. In Geroimenko, V. (ed.) Augmented Reality Art. Springer International, Switzerland.

Tran, H. A. (2015) Urban Space Production in Transition: The cases of the new urban areas of Hanoi. 